\title{
SISTEM CERDAS DALAM PENENTUAN DAUN KELOR SEBAGAI IMUNUSTIMULAN
}

\author{
Wabdillah $^{1}$, Muhajirin ${ }^{2}$ \\ Teknik Komputer ${ }^{1}$, Teknik Informatika ${ }^{2}$, STMIK AKBA \\ Wabdillah@akba.ac.id', aji@akba.ac.id²
}

\begin{abstract}
ABSTRAK
Daun kelor sebagai imunustimulan dapat meningkatkan aktivitas dan fungsi beberapa komponen imunitas. Kelayakan daun kelor sebagai imunustimulan dapat dilihat dengan dua objek. Pertama dengan menentukan kelayakan daun pada fitur warna dan yang kedua dengan cara penentuan kelayakan pada umur daun. Sejalan dengan perkembangan teknologi, telah lama dikenal yang disebut Sistem Cerdas. Sistem cerdas dapat mempermudah dalam pemilihan daun kelor sebagai imunustimulan. Metode penelitian yang digunakan dalam penelitian ini merupakan metode deskriptif dengan analisis yang digunakan untuk perancangan sistem piranti lunak mengikuti pendekatan algoritma permasalahan warna sebagai tolak ukur hubungan untuk perkiraan atau pendugaan umur daun/batang kelor. Untuk itu dalam proses perancangan piranti lunak pengolah citra ini dilakukan pemodelan regresi untuk mendapatkan hubungan korelasi di antara komponen warna RGB dalam menentukan tingkat kelayakan daun kelor. Sistem ini dibuat menggunakan MATLAB R2013b. Hasil Penelitian ini menunjukkan bahwa sistem cerdas ini dapat digunakan untuk mengklasifikasikan tanaman kelor menggunakan algoritma k-Nearest Neighbor ( $k$-NN) dengan perhitungan euclidean distance berdasarkan fitur tekstur. Dalam perhitungan tingkat akurasi menggunakan teknik pengujian $k$-fold cross validation dapat didapatkan hasil akurasi $30,95 \%$.
\end{abstract}

\section{Kata Kunci : Imunustimulan, Daun kelor dan Sistem Cerdas.}

\section{Pendahuluan}

Imunustimulan merupakan imun meningkatkan daya tahan tubuh. Imunustimulan atau biasa dikenal sebagai imun yang sistemnya dalam keadaan normal yang berperan melindungi tubuh (Pringgoutomo, 2006). Ada dua jenis respon yang terjadi bila sistem imun terpapar zat asing yaitu respon imun nonspesifik dan respon imun spesifik. Respon imun spesifik dapat berupa respon imun seluler dan respon imun humoral (Kresno, 2010).

Peran daun kelor sebagai imunustimulan yaitu sebagai salah satu bahan mengekstrak dengan sistem imun, yang dapat meningkatkan aktivitas dan fungsi beberapa komponen imunitas. Uji farmakologi ekstrak metanol daun kelor yang diperoleh ternyata dapat menstimulasi sistem imun seluler dan humoral (Gaikwad, 2011). Ekstak air daun kelor juga dapat meningkatkan Interleukin dan dapat meningkatkan sel limfosit B (Hefni, 2013).

Penentuan kelayakan pada daun kelor yaitu dilihat dengan dua objek. Objek pertama dengan menentukan kelayakan pada fitur warna, apa bila fitur warna yang terdapat pada daun kelor 
berwarna hijau tua maka daun tersebut layak tetapi jika fitur warna kekuningkuningan dan hijau lumut maka daun kelor tersebut tidak layak digunakan sebagai bahan dalam pembuatan imunustimulan. Dan yang kedua dengan cara penentuan kelayakan pada umur daun, jika umur daun berkisar antara 7-18 hari maka duan tersebut layak, tetapi jika daun berumur di bawah 7 hari maka daun tersebut tidak layak digunakan (Kusuma Wijaya, 2008)

Pada penentuan kelayakan daun kelor dapat diketahui layak atau tidaknya. Dilihat pada objek daunnya sebab pada daun kelor dapat diketahui mana yang berumur muda, berumur tua dan daun yang mengalami kerusakan. Batang, bunga, serta buah dapat diketahui hanya dengan melihat usia daun kelor (Makkar dan Becker, 1997).

Dalam rangka memudahkan penentuan kelayakan daun kelor sebagai imunustimulan maka dirancanglah suatu sistem cerdas. Sistem cerdas adalah sistem yang dapat mengadopsi sebagian kecil dari tingkat kecerdasan manusia untuk berinteraksi dengan keadaan eksternal suatu system. Sistem cerdas yang dibuat adalah sistem komputer yang dibuat untuk mempermudah mengetahui jenis daun kelor berdasarkan fitur warna dan umur daun yang baik sebagai mengestrak mentanol. Proses perancangan piranti lunak pengolah citra ini dilakukan pemodelan regresi untuk mendapatkan hubungan korelasi di antara komponen warna RGB dalam menentukan tingkat kelayakan daun kelor. Dengan dirancangnya sistem ini diharapkan dapat mempermudah berbagai pihak yang membutuhkan dalam memilih daun kelor yang layak digunakan sebagai imunustimulan.
Berdasarkan latar belakang tersebut maka akan dilaksanakan penelitian dengan judul "Sistem Cerdas dalam Penentuan Daun Kelor sebagai Imunustimulan”.

\section{Tinjauan Pustaka}

\subsection{Sistem Cerdas}

Menurut John Mc Cathy,( 2000 : 4). Sistem cerdas adalah ilmu rekayasa yang membuat suatu mesin mempunyai intelegensi tertentu khususnya program computer yang "cerdas" . Kecerdasan buatan merupakan kawasan penelitian, aplikasi dan intruksi yang terkait dengan pemograman komputer untuk melakukan sesuatu hal yang dalam pandangan manusia adalah cerdas (Simon, 2002).

Kecerdasan buatan atau sistem cerdas merupakan cabang dari ilmu komputer yang dalam mempresentasikan pengetahuan lebih banyak menggunakan bentuk simbol-simbol dari pada bilangan, dan memproses informasi berdasarkan metode heuristic (Metode Heuristik adalah teknik yang dirancang untuk memecahkan masalah yang mengabaikan apakah solusi dapat dibuktikan benar, tapi yang biasanya menghasilkan solusi yang baik atau memecahkan masalah yang lebih sederhana yang mengandung atau memotong dengan pemecahan masalah yang lebih kompleks.) atau dengan berdasarkan sejumlah aturan (Rich and Knight, 2004).

\subsection{Pengolahan Citra Digital}

Menurut Sutoyo, dkk (2009:5), pengolahan citra digital adalah sebuah disiplin ilmu yang mempelajari hal-hal yang berkaitan dengan perbaikan kualitas gambar (peningkatan kontras, transformasi warna, restorasi citra), transformasi gambar (rotasi, translasi, skala, transformasi geometik), melakukan 
pemilihan cinta cirri (feature images) yang optimal untuk tujuan analisis, melakukan proses penarikan informasi atau deskripsi objek atau pengenalan objek yang terkandung pada citra, melakukan kompresi atau reduksi data untuk tujuan penyimpanan data, transmisi data, dan waktu proses data. Input dari pengolahan citra adalah citra, sedangkan output adalah citra hasil pengolahan.

\subsection{Pemograman GUI Matlab (Matrix Laboratory) R2013b}

Menurut sugiharto (2006:1,9,53), matlab merupakan bahasa pemograman dengan kemampuan tinggi dalam bidang komputasi. Sesuai dengan namanya matlab atau matrix laboratory, maka matrix merupakan dasar yang digunakan matlab dalam komputasi atau operasi yang lainnya. GUIDE atau GUI builDer merupakan sebuah graphical user interface (GUI) yang dibangun dengan obyek grafis seperti tombol (button), kotak teks, maupun menu. Aplikasi yang menggunakan GUI umumnya lebih mudah dipelajari dan digunakan karena orang yang menjalankannya tidak perlu mengetahui perintah yang ada dan bagaimana perintah bekerja.

Menurut Sugiharto (2006:53), matlab merintis kearah pemograman yang menggunakan GUI dimulai dari matlab versi 5, yang terus disempurnakan hingga sekarang. Tidak seperti bahasa pemograman lainnya, GUIDE matlab memiliki banyak keunggulan tersendiri, antara lain :

a. GUI matlab banyak digunakan dan cocok untuk aplikasi-aplikasi berorientasi sains, sehingga banyak peneliiti atau mahasiswa menggunakan GUIDE matlab untuk menyelesaikan tugas akhirnya. b. Matlab memiliki banyak fungsi built in yang siap digunakan dan pemakaian tidak repot membuatnya sendiri.

c. Ukuran file, baik FIG-file maupun $M$ file, yang dihasilkan relative kecil.

Kemampuan grafisnya cukup andal dan tidak kalah dibandingkan bahasa pemograman lainnya.

\subsection{Daun Kelor}

Kelor memiliki akar tunggang, berwarna putih membesar seperti lobak, merupakan tumbuhan yang berbatang dan termaksud jenis batang berkayu, permukaannya kasar. Daunnya majemuk, bertangkai panjang, tersusun berseling, beranak daun gasal, heladaun saat muda berwarna hijau muda, setelah dewasa hijau tua, bentuk helai daun bulat telur, panjang 1-2 cm, lebar 1-2 cm, tipis lemas, ujung dan pangal tumpul, tepi rata, susunan pertulangan menyirip, permukaan atas dan bawah halus. Bangun daunnya berbentuk bulat atau bundar, pangkal daunnya tidak bertoreh dan termaksud ke dalam bentuk bangun bulat telur. Kelor memppunyai tepi daun yang rata dan healian daunnya tipis dan lunak, permukaannya licin dan berselaput lilin (Krisnadi, 2006).

Bunganya berwarna putih kekunigkuningan terkumpul dalam pucuk lembaga dibagia ketiak dan tudung pelepah bunganya berwarna hijau. Buah atau polong Kelor berbentuk segi tiga memangjang dengan panjang 20-60 cm, ketika mudah berwarna hijau setelah tua menjadi cokelat, biji di dalam polong berbentuk bulat, ketika muda berwarna hijau terang dan berubah berwarna coklat kehitaman ketika polong matang dan kering (Krisnadi, 2006).

Adapun jenis-jenis daun kelor yang akan diteliti antara lain : 
a. Daun kelor berumur dibawah 1 - 4 minggu (sangat muda)

Daun kelor yang berumur di bawah 1- - 4 minggu berbentuk lonjong pada ujung daun, warna daun berwarna hijau muda, serta batang daun masih sangat fleksibel.

b. Daun kelor berumur $5-7$ minggu (muda)

Daun kelor yang berumur $5-7$ minggu atau merupakan jenis daun kelor muda, memiliki warna daun hijau muda, bentuk helai daun secara keseluruhan berbentuk bulat telur, serta batang daun tidak fleksibel.

c. Daun kelor berumur $>7$ minggu (tua)

Daun kelor berumur $>7$ minggu atau tua memiliki warna daun hijau tua, warna pada batang daun berubah menjadi hijau tua, mempunyai bunga berwarna putih kekuning-kuningan yang terkumpul dalam pucuk lembaga di bagian ketiak dan tudung pelepah bunganya berwarna hijau, terdapat pula buah atau polong kelor yang berbentuk segi tiga memanjang dengan panjang $20-60 \mathrm{~cm}$, ketika mudah berwarna hijau setelah tua menjadi cokelat.

d. Daun kelor yang mengalami kerusakan

Daun kelor yang mengalami kerusakan ditandai dengan terlihatnya daun yang berbintik-bintik kuning bahkan terdapat warna daun yang secara keseluruhan berubah warna menjadi kuning tanpa memandang usia dari daun tersebut.

\section{Metode Penelitian}

Tahapan penelitian dalam mengimplentasikan sistem cerdas mampu mendeteksi daun kelor sebagai imunustimulan adalah :

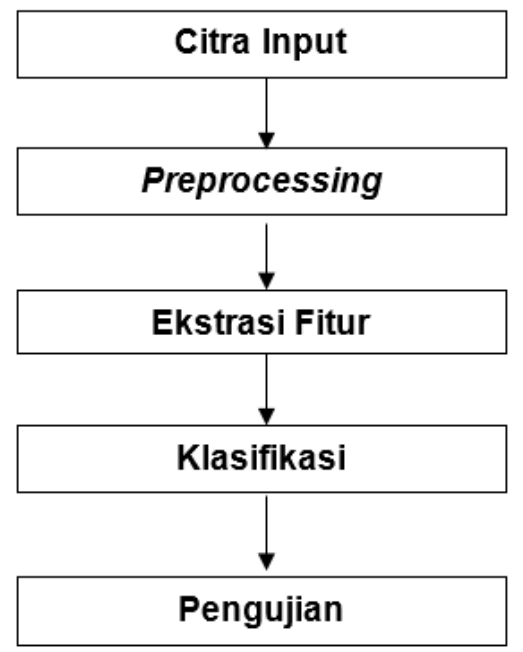

Adapun metode analisis yang dilakukan adalah sebagai berikut:

a. Citra Input

Pengambilan sampel citra daun kelor dilakukan dengan meng-capture citra sampel daun daun kelor menggunakan kamera digital berukuran maksimal 5 megapiksel. Langkah-langkah dalam akuisisi citra diantaranya : mengambil sampel daun kelor, kemudian diletakkan di atas kain berwarna putih atau memiliki latar belakang berwarna putih dengan kondisi pencahayaan ruangan yang sama atau penyinaran, posisi kamera tegak lurus dengan objek dan dengan ketinggian $15 \mathrm{~cm}$, lalu dilakukan pengambilan citra.

b. Preprocessing

Pre memiliki makna yaitu sebelum. Preprocessing adalah tahapaan melakukan ekstrasi fitur. Tahapan yang dilakukan dalam preprocessing yaitu, proses cropping dilakukan untuk menghilangkan bagian-bagian citra yang tidak perlu dan didapat citra dengan ukuran yang seragam. Citra hasil cropping ini 
berikutnya akan masuk ke proses ekstraksi fitur ciri dengan terlebih dahulu diubah kemode warna grayscale.

Citra yang akan dilakukan proses deteksi, pertama-tama akan diubah menjadi citra grayscale. Hal ini perlu dilakukan karena proses pengolahan atau pendeteksi citra warna lebih sulit dilakukan karena citra warna mengandung tiga komponen warna utama (merah, hijau, biru). Citra warna membutuhkan proses pengolahan atau pendeteksian yang lebih kompleks dari pada citra grayscale. Oleh karena itu citra perlu di diubah terlebih dahulu menjadi citra grayscale untuk mempermudah dalam proses pengolahan citra, dimana citra grayscale, batas antara objek dengan latar belakang terlihat jelas. Citra yang akan dilakukan proses deteksi, pertama-tama akan diubah menjadi citra grayscale. Hal ini perlu dilakukan karena proses pengolahan atau pendeteksi citra warna lebih sulit dilakukan karena citra warna mengandung tiga komponen warna utama (merah, hijau, biru). Citra warna membutuhkan proses pengolahan atau pendeteksian yang lebih kompleks dari pada citra grayscale. Oleh karena itu citra perlu di diubah terlebih dahulu menjadi citra grayscale untuk mempermudah dalam proses pengolahan citra, dimana citra grayscale, batas antara objek dengan latar belakang terlihat jelas.

c. Ekstaksi Fitur

Ekstraksi fitur dilakukan untuk mendapatkan ciri tekstur dari citra daun kelor yang akan dilatih maupun citra yang akan diuji. Citra yang akan diekstrak dibagi menjadi dua bagian, yaitu data latih dan data uji. Citra yang digunakan ada 2 komponen diantaranya berdasarkan warna daun dan umur daun.

Setelah mengalami proses pengubahan warna, citra diekstrak dengan metode ekstraksi ciri fitur yaitu : rata-rata intensitas (maen), smoothness, entropy, uniformity dan PSNR dari pendekatan matrik cooccurrence. Ciri latih yang disimpan akan dibandigkan dengan ciri citra uji pada tahapan klasifikasi.

d. Klasifikasi

Klasifikasi dilakukan dengan $k$ Nearest Neighbor. K-Nearest Neighbor $(k-N N)$ adalah metode pengukuran kemiripan yang sederhana. Penelitian ini menggunakan pengukuran kemiripan berdasarkan Euclidean distance. Analisi yang dilakukan pada $k-N N$ adalah pengaruh penggunaan pengukuran kemiripan dan nilai $k$ yang digunakan terhadap akurasi sitem dalam mengklasifikasi jenis daun jeruk. Nilai $k$ yang di uji adalah nilai $k$ yang ganjil agar mengurangi kesalahan algoritma jika peluang kemiripannya sama.

\section{e. Pengujian}

Teknik pengujian yang digunakan yaitu teknik cross validation. Untuk menggunakan jumlah fold terbaik untuk uji validitas digunakan 10-fold cross validation. Penggunaan 10 fold ini dianjurkan karena merupakan jumlah fold terbaik untuk uji validitas.

Analisis performansi sistem untuk parameter akurasi sistem, ditentukan dengan banyaknya pengujian tepat dengan banyaknya seluruh pengujian. 


\section{Hasil Penelitian dan Pembahasan}

Pemetaan Alur Kerja Sistem

Tabel 1. Pemetaan alur kerja sistem

\begin{tabular}{|c|c|c|}
\hline No. & Alur Kerja & Fungsi Kode File \\
\hline 1 & Menentukan Group & Init.m \\
\hline 2 & Menyimpan Data Group & Init.m \\
\hline 3 & Menentukan Data Latih & $\begin{array}{l}\text { Dlg.m } \\
\text { Tsetting.m }\end{array}$ \\
\hline 4 & Menyimpan Data Latih & td.m \\
\hline 5 & Menentukan Data Uji & $\begin{array}{l}\text { Single_test.m } \\
\text { analyzeAll.m }\end{array}$ \\
\hline 6 & Menyimpan Data Uji & $\begin{array}{l}\text { Single_test.m } \\
\text { analyzeAll.m }\end{array}$ \\
\hline 7 & Memulai Aplikasi & Kelor.m \\
\hline 8 & $\begin{aligned} & \text { Memproses Analisa } \\
& \text { Data Latih } \\
> & \text { Clipping } \\
> & \text { Segmentasi } \\
> & \text { Ekstraksi Fitur Tekstur }\end{aligned}$ & $\begin{array}{l}\text { td.m } \\
\text { clipping.m } \\
\text { dimension.m } \\
\text { statxture.m } \\
\text { glcm_energy.m } \\
\text { psnir.m } \\
\text { statmoments.m }\end{array}$ \\
\hline 9 & $\begin{aligned} & \text { Memproses Analisa } \\
& \text { Data Uji } \\
& \text { Clipping } \\
> & \text { Segmentasi } \\
> & \text { Ekstraksi Fitur Warna }\end{aligned}$ & $\begin{array}{l}\text { td.m } \\
\text { clipping.m } \\
\text { dimension.m } \\
\text { statxture.m } \\
\text { glcm_energy.m } \\
\text { psnr.m } \\
\text { statmoments.m }\end{array}$ \\
\hline 10 & $\begin{array}{l}\text { Extract dan } \\
\text { Classification }\end{array}$ & knnclassify.m \\
\hline 11 & $\begin{array}{l}\text { Menyimpan } \quad \text { Data } \\
\text { Classify }\end{array}$ & knnclassify.m \\
\hline 12 & $\begin{array}{l}\text { Menentukan Hasil } \\
\text { Analisa }\end{array}$ & $\begin{array}{l}\text { single_test.m } \\
\text { analyzeAll.m }\end{array}$ \\
\hline 13 & Selesai & kelor.m \\
\hline
\end{tabular}

\section{Paparan Kerja Fungsi}

Fungsi kelor.m adalah fungsi MATLAB yang digunakan untuk memulai aplikasi $k-N N$ kelor dan fungsi ini berfungsi sebagai antarmuka utama bagi pengguna aplikasi $k$-NN kelor dengan semua fungsi yang ada dalam aplikasi $k$ NN kelor.

Untuk memulai aplikasi $k-N N$ kelor pada jendela "command window" dalam aplikasi MATLAB, $k$-NN kelor dipanggil dengan menginput kata "Kelor" pada prompt command dan di ikuti dengan menekan ENTER untuk eksekusi fungsi.

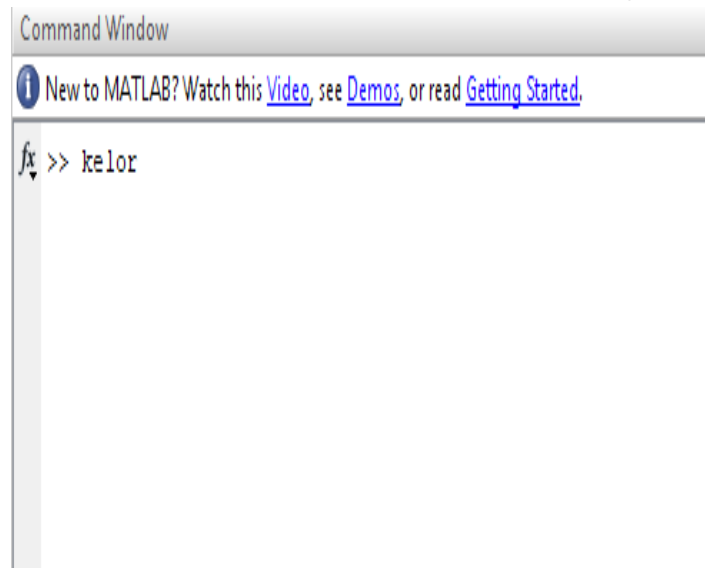

Gambar 2. Panggilan aplikasi pada

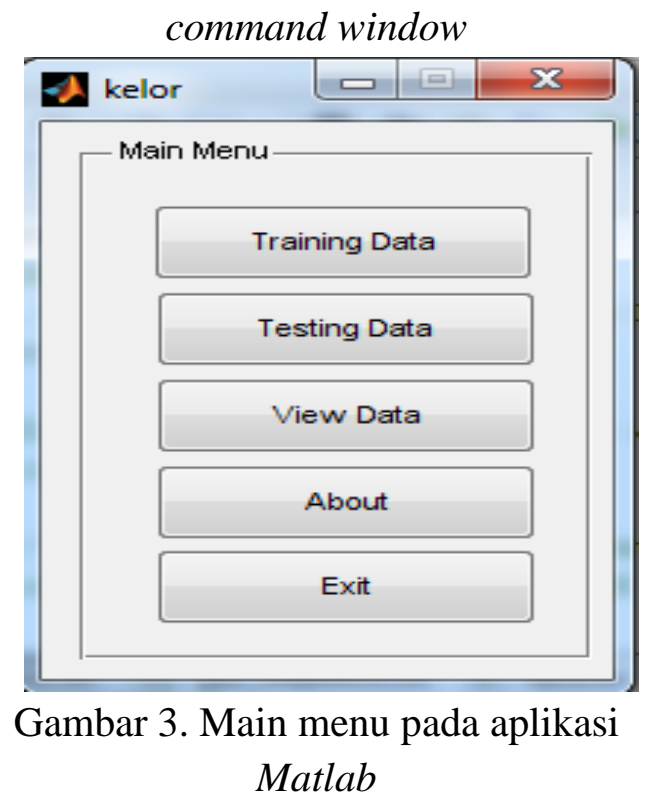

Di setiap awal proses, aplikasi akan selalu memanggil fungsi-fungsi utama sebagai fungsi wajib yang harus dijalankan di awal proses sebelum aplikasi dapat dinyatakan siap untuk digunakan.

\subsection{Proses Analisa Klasifikasi $k$-Nearest Neighbor $(\boldsymbol{k}-\mathrm{NN})$.}

Aplikasi $k-N N$ kelor melakukan proses analisa dengan mengeksekusi fungsi 
nayzeAll.m atau single_test.m, baik analyzeAll.m ataupun single_test.m keduaduanya mempunyai fungsi yang sama, yaitu melakukan proses klasifikasi $k$ Nearest Neighbor $(k-N N)$ dan perbedaannya adalah jika analyzeAll.m digunakan untuk melakukan proses pada lebih dari satu file JPG sementara single_test.m hanya melakukan proses untuk satu file JPG saja.

Selanjutnya, keterangan berikut adalah tahapan dalam proses yang dilakukan pada single_test.m.

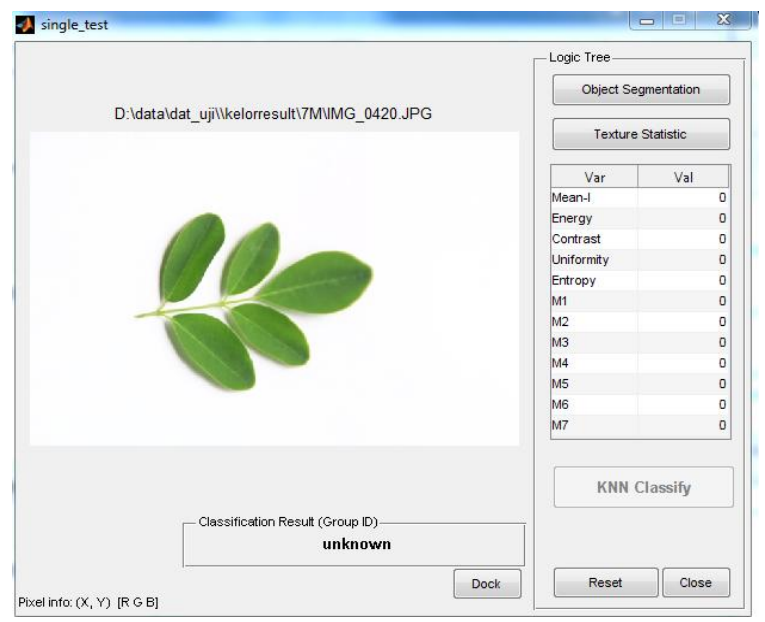

Gambar 4. Form Testing

Dalam melakukan prosesnya ada beberapa tahapan, yaitu sebagai berikut :

1) Clipping (clipping.m) : fungsi melakukan pembacaan atas data citra yang di-input sebagai sebuah file berekstensi JPG, yang bertujuan untuk meminimilisasi pembacaan citra pada latar belakang dari citra utamanya.

Fungsi akan mengkonversi data citra ke dalam mode grayscale. Selanjutnya fungsi akan memisahkan mana-mana dari mode warna grayscale (abu-abu) yang termasuk ke dalam warna terang atau warna gelap dengan melakukan uji gray-thresthold-test yang bertujuan mencari batas (edge) transisi antara warna terang dan warna gelap sebagai batas tepi.

Batas-tas minimum dan maksimum dari hasil pengujian pada sumbu horizontal $\mathrm{X}$ dan sumbu vertical $\mathrm{Y}$ akan dijadikan acuan fungsi untuk memotong citra secara horizontal maupun vertical :

$\mathrm{X}=\mathrm{Xmin}$ dengan Panjang $=\mathrm{Xmax}-$ $X \min$;

$\mathrm{Y}=\mathrm{Ymin}$ dengan Tinggi $=\mathrm{Ymax}-$ Ymin.

Jika data adalah citra pada file "Nipis_1.2.jpg"

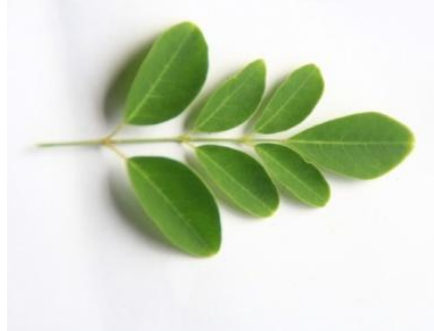

Gambar 5 File citra uji

2) Segmentasi (dimension.m): berbeda dengan fungsi clipping.m. dimension.m berfungsi sebagai segmentasi citra grayscale dengan memisahkan citra berdasarkan deteksi tepi yang menghasilkan kontur kurva tertutup antara bagian dalam kurva (obyek) dan bagian luar kurva (latar belakang) dan obyek inilah yang akan menjadi target analisa atau yang sering disebut dengan ROI (Region if Interest). Selain sebagai fungsinya meminimalisasi citra non-obyek. Fungsi inipun dapat berfungsi untuk memisahkan bagian citra yang mempunyai obyek yang lebih jelas dan obyek yang mengalami kerusakan yang diakibatkan oleh proses awal pengambilan citra (misalkan : kamera bergoyang pada saat pemotretan).

Jika diperoleh hasil segmentasi lebih dari satu segmen, maka aplikasi 
$k-N N$ daun akan memilih segmentasi degan area terluas.

Hasil dari fungsi Clipping dan Segmentasi adalah sebagai berikut ;

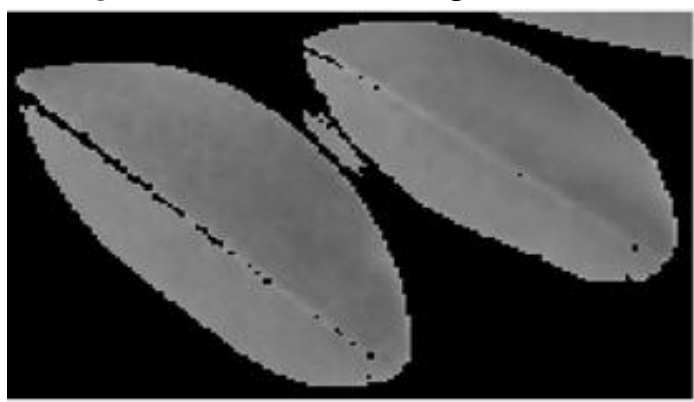

Gambar 6. File citra uji mode grayscale

3) Ekstraksi Texture

Fungsi yang memproses data citra dengan mencari cirri-ciri tertentu citra yang telah dikonversiu ke dalam mode abu (grayscale).

a) Stastistical Textures

$$
\begin{aligned}
& \checkmark \text { energy (GLC } \\
& \text { glcm_energy.m) } \\
& \checkmark \text { mean Intensitas (statxture.m) } \\
& \checkmark \text { smoothness (statxture.m) } \\
& \checkmark \text { mean Contrass (statxture.m) } \\
& \checkmark \text { uniformity (statxture.m) } \\
& \checkmark \text { entropy (statxture.m) } \\
& \checkmark \text { PSNR (psnr_value.m) }
\end{aligned}
$$

b) Geometric Invariant Moments (invmoment.m)

Penurunan Moment ke-1 sampai dengan Moment ke-7

4) Klasifikasi $k$-Nearest Neighbor (knncalssify.m)

Proses klasifikasi $k$-Nearest Neighbor $(k-N N)$ dengan variable data dan variable tetap yang terdiri dari :
a) Data Label Group
b) Data Latih
c) Data Uji
d) Metode Perhitungan Jarak (Euclidean)
e) Nilai Maksimum $k$

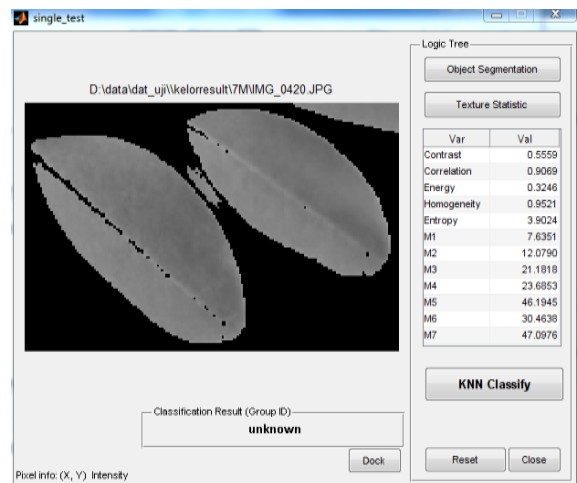

Gambar 7. Form Testing

\subsection{Pembahasan Listing Program}

Berikut akan dibahas Sistem cerdas klasifikasi daun kelur berdasarkan fitur warna dan umur daun menggunkan metode $k$-Nearest Neighbor (k-NN) yang dilengkapi dengan Listing masing-masing form.

\section{Form Data Training}

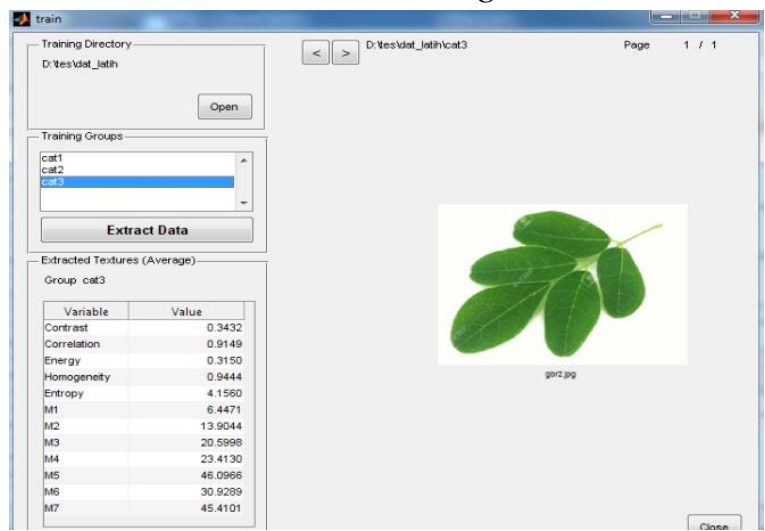

Gambar 8. Form data training

Listing program pada fungsi tsetting.m sebagai berikut :

Berikut adalah sebagian script untuk mengextract data yang ada pada Listbox training group yang akan menghasilkan data $k-N N$ pada data taining.

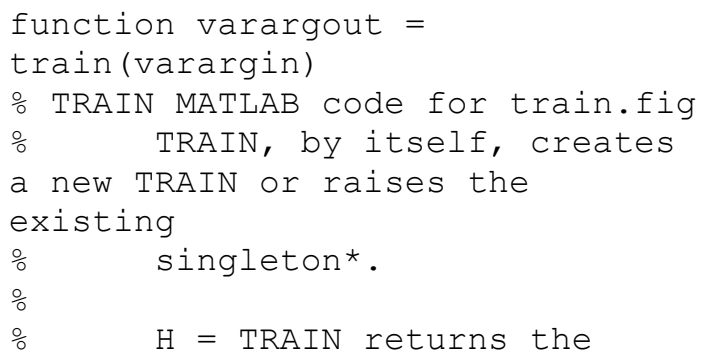


Listbox dan sebagian scrip untuk membuka file yang telah dibuat sebagai data latih.

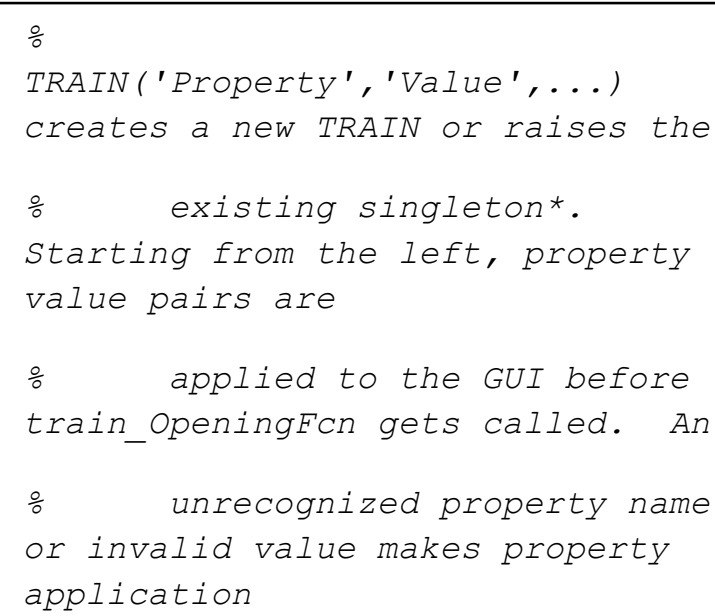

2. Form Utama

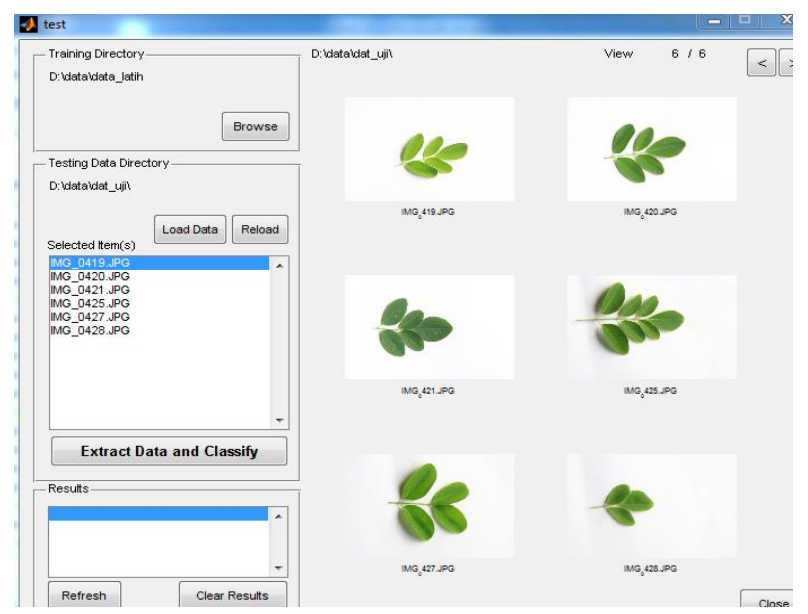

Gambar 9 Form utama aplikasi $k-N N$ kelor

Sebagian Listing program pada fungsi kelor.m sebagai berikut :

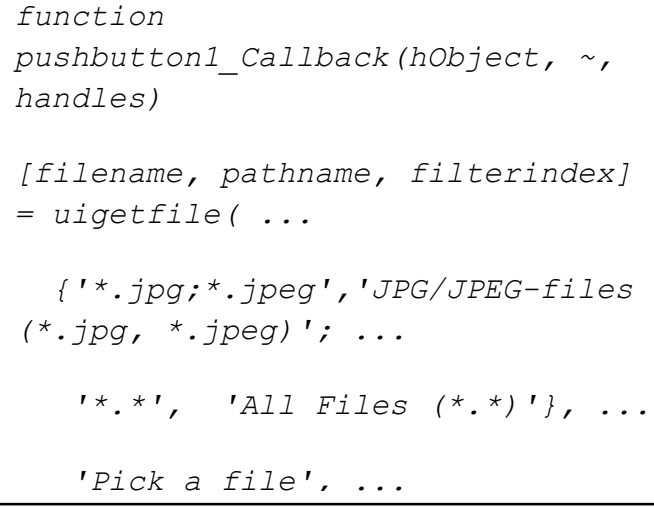

\subsection{Pengujian dengan $k$-fold cross validation}

Jika diperoleh hasil segmentasi lebih dari satu segmen, maka aplikasi $k-N N$ daun akan memilih segmentasi degan area terluas.

Pengujian yang dilakukan adalah dengan menggunakan data training sebagai pelatihan terhadap sistem, kemudian memasukan data uji untuk melakukan klasifikasi. Hasil klasifikasi data uji oleh sistem dibandingkan dengan klasifikasi data uji yang sesungguhnya. Analisis dilakukan dengan membandingkan antara data uji yang berhasil diklasifikasi dengan benar dengan semua data uji, maka didapatkan akurasi sistem klasifikasi jenis daun kelor tersebut berdasarkan warna.

Hasil ekstraksi fitur tekstur contrass, correlation, energy, homogeneity, entropy serta 7 moment invariants terhadap citra referensi dapat dilihat pada

Tabel 2 Hasil ekstraksi cirri fitur tekstur statistic pada citra daun kelor

\begin{tabular}{|c|l|l|l|l|l|l|}
\hline $\begin{array}{l}\text { DATA } \\
\text { KE }\end{array}$ & CLASS & Contrass & Correlation & Energy & Homogenety & Entropy \\
\hline 1 & MUDA & 0,5515 & 0,9144 & 0,2577 & 0,9366 & 4,9811 \\
\hline 2 & MUDA & 0,5420 & 0,9154 & 0,2579 & 0,9466 & 4,9912 \\
\hline 3 & MUDA & 0,5724 & 0,9214 & 0,2880 & 0,9470 & 5,0111 \\
\hline 4 & MUDA & 0,5144 & 0,8917 & 0,2143 & 0,9011 & 4,9241 \\
\hline 5 & MUDA & 0,4968 & 0,8813 & 0,1996 & 0,8867 & 4,8818 \\
\hline
\end{tabular}

Dari hasil pengujian dapat dilihat klasifikasi dengan $k=3$ memberikan akurasi yang didapatkan dari nilai masingmasing data dibagi jumlah data dikali $100 \%$ maka di dapatkan hasil 30,95\% yang terdapat pada hasil pengujian kelor mudah (1-4 minggu), hasil akurasi kelor sedang $28,26 \%$ dan akurasi hasil kelor tua $27,90 \%$. 


\section{DAFTAR PUSTAKA}

[1]. Gaikwad, S. B., Mohan, G. K. dan Reddy, K. J. 2011. Moringa oleivera Leaves : immunomodulation in Wistar Albino Rats. International Journal Of Pharmacy and Pharmaceutical Sciences, 426 - 427

[2]. Hefni, M., Rifai'I, M. 2016. Aktivitas Ekstrak Daun Kelor terhadap Respon Imun Humoral. Jurnal Veteriner. 520.

[3]. Kresno, S. B. 2010. Imunologi Diagnosis dan Prosedur Laboratorium. Falkultas Kedokteran Indonesia : Jakarta.

[4]. Krisnadi, 2006. Pusat Informasi Dan Pengembangan Tanaman Kelor Indonesia.

[5]. Rich. dan Knight. Kecerdasan Buatan. Yogyakarta.

[6]. Sugiharto, T.2004. Pemograman GUI dengan MATLAB. Yogyakarta: Penerbit Andi.

[7]. Sutoyo. Mulyanto. Dkk. 2009. Teori Pengolahan Citra Digital. Yogyakarta: Penerbit Andi.

[8]. Simon, H, A. 2002. Kecerdasan Buatan. Yogyakarta. 